Izvirni znanstveni članek/Original scientific article

\title{
Pogled študentov magistrskega študija vzgoje in menedžmenta v zdravstvu na pridobljeno znanje
}

\author{
The views of master students of the study programme "Education and management in \\ health care" on the acquired knowledge
}

Bojana Filej

\section{Ključne besede: odgovornost; kompetence; moč; medicinska sestra}

Key words: responsibility; competences; power; nurse

doc. dr. Bojana Filej, univ. dipl. org., viš. med. ses.; Alma Mater Europaea - ECM, Gosposka ulica 1, 2000 Maribor

Kontaktni e-naslov/ Correspondence e-mail: bojana.filej@gmail.com
Prejeto/Received: 29. 11. 2014 Sprejeto/Accepted: 26. 5. 2015

\section{IZVLEČEK}

Uvod: Zaradi hitrega razvoja znanosti in hitro spreminjajočega se okolja je izobraževanje in učenje v vseh obdobjih človekovega življenja nujno. Z raziskavo smo želeli ugotoviti, kako študenti magistrskega študija vzgoje in menedžmenta v zdravstvu dojemajo svoje novopridobljeno znanje.

Metode: Raziskava je temeljila na kvantitativni metodi raziskovanja. Podatke smo zbrali s pomočjo spletnega anketnega vprašalnika. V raziskavo smo vključili tri generacije študentov, vpisanih na magistrski študijski program vzgoje in menedžmenta v zdravstvu $(n=61)$. Vrnjenih je bilo $39(63,9 \%)$ anketnih vprašalnikov. Za analizo zanesljivosti anketnega vprašalnika smo uporabili Cronbachov koeficient alfa, ki je znašal 0,86. Statistična značilnost je bila preverjena na ravni $5 \%$ tveganja $(p=0,05)$. Za testiranje domnev o razliki aritmetičnih sredin smo uporabili enofaktorsko analizo variance in za ugotavljanje jakosti korelacij med spremenljivkami Pearsonov korelacijski koeficient $(r)$.

Rezultati: Anketirani se ne glede na mesto zaposlitve (bolnišnica, zdravstveni dom, socialnovarstveni zavod, zasebnik, izven zdravstva, brez zaposlitve) najbolj strinjajo s trditvama, da jim znanje daje strokovno moč $(\bar{X}=4,7)$ in da se z znanjem krepi profesija zdravstvene nege $(\bar{X}=4,7)$. Najmanj se strinjajo s trditvijo, da bodo po zaključku študija prerazporejeni na drugo delovno mesto $(\bar{X}=2,1)$. Statistično pomembna razlika se nanaša na trditev, da jih bodo člani zdravstvenega tima bolj spoštovali, ker bodo imeli višji naziv $\left(F^{\star}=5,059\right.$, $p=0,012)$.

Diskusija in zaključek: Zaradi krizne situacije zavodi novopridobljenega znanja svojih zaposlenih ne bodo mogli izkoristiti v celoti; magistrski študenti pa ga bodo po dokončanju študija lahko koristno uporabili pri obravnavi pacientov, $\mathrm{s}$ čimer bodo prispevali k razvoju in profesionalizaciji stroke zdravstvene nege.

\footnotetext{
ABSTRACT

Introduction: Due to the rapid development of science and the ever-changing environment, education and lifelong learning became an imperative. The main objective of this study was to measure the attitudes and opinions regarding the knowledge acquired through master's degree preparation in nursing. The sample included the students of the master study programme "Education and management in health care".

Methods: The research was based on a quantitative research method. The data were obtained through a web questionnaire which included three generations of students $(n=61)$ enrolled in the master study programme "Education and management in health care". The survey's response rate was $63.9 \%(n=39)$. The reliability was calculated through Cronbach's alpha coefficient amounting to 0.86 . This statistical characteristic was tested at the level of $5 \%$ risk $(p=0.05)$. To test the hypothesis about the difference of arithmetic means, factor variance analysis was used, while the Pearson's correlation coefficient was used to determine the strength of correlations between variables.

Results: Respondents from all institutions (hospitals, health centres, homes for the elderly, private individuals, employees from non-medical institutions, unemployed) reported highest levels of agreement with the statement that education gives them professional and expert power $(\bar{X}=4.7)$, and that knowledge strengthens the profession $(\bar{x}=4.7)$. The level of agreement was found to be lowest for with the statement that they might be transferred to a different work place after graduation $(\bar{X}=2.1)$. A statistically significant difference refers to the statement that the members of their health team will respect them more due to their higher education and title $\left(F^{*}=5.059, p=0.012\right)$.

Discussion and conclusion: Institutions will not be able to take full advantage of the newly acquired knowledge of their staff due to unfavourable economic conditions. The graduates of the master programme will in turn apply their knowledge in the provision of care, hereby contributing to quality of patient care, development and professionalization of nursing.
} 


\section{Uvod}

Ljudje imajo vedno potrebe po znanju, in kot navaja Parahoo (2006), je v znanju moč. Na prvi pogled je vsebina besede "znanje" popolnoma jasna, vendar ugotavljamo, da temu ni tako, saj obstajajo številne med seboj različne definicije, ki se razlikujejo tudi v odvisnosti od znanstvenega področja.

Strokovnjaki v zdravstveni negi imajo strokovno znanje zdravstvene nege, ki so si ga pridobili z izobraževanjem, prakso in kontinuiranim izpopolnjevanjem. $Z$ vertikalo izobraževanja $\mathrm{v}$ zdravstveni negi se povečuje kakovost izvajanja zdravstvene nege in s tem obravnave pacienta. Gerrish \& Lacey (2010) navajata, da tako kot drugo znanje tudi znanje zdravstvene nege ni nikoli absolutno, saj se zdravstvena nega razvija in prilagaja spremembam okolja, zato je znanje vedno začasno in delno.

Znanje je tudi element pridobljenih kompetenc, ki obsegajo še "veščine, spretnosti, osebnostne in vedenjske značilnosti, prepričanja, vrednote in samopodobo « (Gruban, 2004). Kompetence se razvijajo tudi $\mathrm{z}$ vseživljenjskim izobraževanjem.

Zdravstvena nega je na znanju temelječa disciplina z lastnim obsegom znanja, kar ji daje možnost razvoja neodvisne znanstvene discipline (Cardoso \& Paiva e Silva, 2010). Veliko znanja si »izposodi« pri drugih znanostih, na osnovi katerega razvija specifično znanje za disciplino zdravstvene nege (Hicks \& Butkus, 2011), po katerem se razmejuje in razlikuje od drugih strok (Hajdinjak \& Meglič, 2006). Tudi Christensen (2011) navaja, da je bilo narejenih mnogo poskusov, da bi identificirali znanje, specifično za zdravstveno nego. Meni tudi, da mora biti "izposojeno" znanje kritično ocenjeno in da je potrebno opredeliti, kakšne modifikacije so potrebne, da se to znanje lahko vključi v znanje zdravstvene nege (angl. body of knowledge).

Razvoj znanja $\mathrm{v}$ zdravstveni negi je postopoma prešel od faze odvisnosti in adaptacije znanja drugih disciplin do razvoja "edinstvenega « znanja zdravstvene nege (Hicks \& Butkus, 2011). Tako se je v zdravstveni negi razvila njena strukturna hierarhija znanja, ki jo tvori pet elementov, ki vključujejo različne stopnje znanja od najbolj konkretne (empirični indikatorji) pa do najbolj abstraktne (metaparadigma) (Hajdinjak \& Meglič, 2006).

Danes govorimo o konceptu vseživljenjskega učenja, $\mathrm{s}$ pomočjo katerega obnavljamo staro in pridobivamo novo znanje. Vseživljenjsko učenje $\mathrm{v}$ zdravstveni negi je namenjeno vsaki posamezni medicinski sestri $\mathrm{v}$ vseh obdobjih njenega profesionalnega življenja. Znanje zdravstvene nege je definirano kot teoretično in izkustveno znanje, ki se zahteva za razvoj discipline in stroke (Sochan, 2011).

Znanje posameznika je pomembno za uspešno delovanje organizacije, in kot navaja Sitar (2006), lahko za znanje organizacije uporabimo tudi pojem intelektualni kapital. Povsem jasno je, da organizacija znanja ne more ustvariti sama, temveč ga ustvarjajo zaposleni, imenujemo ga človeški kapital, znanje pa odide iz organizacije skupaj z njimi. Fink (2006) meni, da je največje bogastvo organizacije prav človeški kapital, zato je pomembno vlagati v razvoj zaposlenih.

Moč je koncept, ki se nanaša na sposobnost vplivanja in motiviranja za doseganje določenega cilja in se prepleta s konceptom opolnomočenja. Opolnomočenje kot pojem v zdravstvu ni dobro definirano (Millard et al., 2006; Mcallister, et al., 2012), nekateri avtorji ga opisujejo kot proces, nekateri kot rezultat. Razumeti ga je mogoče kot zavesten prevzem nadzora (npr. nad stroko zdravstvene nege). Ne glede na pogostoma različne razlage pa ima dva osnovna pomena: "imeti moč» (angl. power) ter "izvor moči in načini za njeno povečanje» (angl. empower) (Angelman \& Berman, 2007). Opolnomočenje ne more obstajati brez moči, med tem ko moč lahko brez opolnomočenja (Manojlovich, 2007; Rao, 2012). Opolnomočenje obstaja na nivoju posamezne medicinske sestre znotraj določenega delovnega okolja in je vgrajeno v zdravstveni sistem, tako da je moč stroke zdravstvene nege dogovorjena med člani različnih disciplin.

Navedena dejstva so bila izhodišče za našo raziskavo, katere namen je bil ugotoviti, kako študenti magistrskega študijskega programa vzgoje in menedžmenta v zdravstvu dojemajo svoje novopridobljeno znanje in kakšna je povezanost med znanjem, kompetencami, odgovornostjo in družbeno pomembnostjo stroke zdravstvene nege.

\section{Metode}

Raziskava je temeljila na kvantitativnem pristopu. Uporabili smo deskriptivno metodo za pojasnitev in razumevanje teme, ki smo jo obravnavali. Podatke smo pridobili s spletnim anketnim vprašalnikom.

\section{Opis instrumenta}

Za pridobivanje podatkov smo na podlagi literature izdelali spletni anketni vprašalnik. Za analizo zanesljivosti anketnega vprašalnika smo uporabili Cronbachov koeficient alfa, ki je znašal 0,86, kar pomeni, da gre za visoko zanesljivost vprašalnika.

$\mathrm{V}$ prvem delu anketnega vprašalnika smo pridobivali splošne demografske podatke anketirancev, $\mathrm{v}$ drugem delu pa njihova mnenja o pomenu znanja za posameznika, za organizacijo, za stroko ter paciente in splošne trditve o znanju. Anketni vprašalnik je obsegal 40 trditev, ki so jih anketirani posamično ocenili po petstopenjski Likertovi lestvici strinjanja ( 1 - sploh se ne strinjam, 2 - delno se strinjam, 3 - niti se ne strinjam, niti se strinjam, 4 - delno se strinjam, 5 - v celoti se strinjam).

\section{Opis vzorca}

Uporabili smo neslučajnostni, namenski vzorec. Anketni vprašalnik smo posredovali študentom magistrskega študijskega programa vzgoje in menedžmenta vzdravstvu, ki se izvaja kot izredni študij. V raziskavo smo zajeli tri 
generacije vpisanih študentov $(\mathrm{n}=61)$, vsi so diplomirane medicinske sestre/diplomirani zdravstveniki in vsi so zaposleni. Velikost vzorca je 61 študentov. Vrnjenih je bilo 39 vprašalnikov, kar predstavlja $63,9 \%$ realizacijo vzorca. V raziskavi je sodelovalo 33 (84,6 \%) žensk, 6 $(15,4 \%)$ moških s povprečno delovno dobo 12,9 let (min. 0,6 , maks. 34,0 let). Večina - 17 (43,6 \%) anketiranih je zaposlenih $\mathrm{v}$ bolnišnici, $\mathrm{v}$ zdravstvenem domu jih je zaposlenih 13 (33,3\%), v socialnovarstvenem zavodu 2 $(5,1 \%)$, pri zasebniku $3(7,7 \%)$, izven zdravstva $3(7,7 \%)$ in $1(2,6 \%)$ anketirani ni zaposlen.

\section{Opis poteka raziskave in obdelave podatkov}

Anketni vprašalnik smo študentom posredovali v obliki spletne ankete, ki so jo lahko izpolnjevali od 24. marca do vključno 29. marca 2013. Za testiranje domnev o razliki aritmetičnih sredin (vzorec večji od 30) smo uporabili enofaktorsko analizo variance $\mathrm{z}$ namenom, da bi ugotovili, ali so razlike med vzorci razložljive kot statistična odstopanja znotraj iste populacije. Statistično značilnost smo preverili na ravni $5 \%$ tveganja $(p=$ $0,05)$. Na začetku vprašalnika smo študente seznanili $\mathrm{z}$ namenom in cilji raziskovanja ter jih zaprosili za sodelovanje $\mathrm{v}$ anketi. Pojasnili smo jim tudi, da je sodelovanje $\mathrm{v}$ raziskavi prostovoljno in anonimno ter da izpolnjevanje anketnega vprašalnika lahko kadar koli prekinejo. Podatke smo analizirali s statističnim programom SPSS 20.0.

\section{Rezultati}

V Tabeli 1 so prikazane ocene strinjanja s trditvami za vse zavode (»vsi zavodi« je v nadaljevanju skupno poimenovanje za bolnišnico, zdravstveni dom ter ostalo: socialnovarstveni zavod, zasebnik, izven zdravstva, brez zaposlitve; te štiri možnosti so v nadaljevanju skupaj poimenovane tudi »drugi zavodi«) in ocene strinjanja s trditvami $\mathrm{z}$ ozirom na mesto zaposlitve anketiranih. Iz tabele povzemamo le rezultate trditev $\mathrm{z}$ največjim in najmanjšim strinjanjem.

Izmed 40 trditev so se anketirani najbolj strinjali s trditvijo "znanje mi daje strokovno moč« $(\bar{X}=4,8, s=$ $0,7)$ in s trditvami: »znanje je moj intelektualni kapital«, "Z znanjem se krepi profesija zdravstvene nege« in »za svoje delo sem odgovoren « $(\bar{X}=4,7, s=0,9)$. Najmanj so se anketirani strinjali s trditvijo "po zaključku študija bom prerazporejen na drugo delovno mesto « $(\bar{X}=2,1, s=$

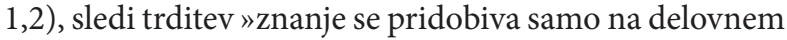
mestu v neposredni praksi« $(\bar{X}=2,3, s=1,3)$.

Zozirom na zavod zaposlitve so se zaposleni vzdravstvenem domu najbolj strinjali $\mathrm{z}$ naslednjimi trditvami: $» \mathrm{Z}$ znanjem se krepi profesija zdravstvene nege«, "za svoje delo sem odgovoren « in "znanje je osnova za pridobivanje kompetenc « $(\bar{X}=4,7, s=1,1)$ in s trditvama: »znanje mi daje strokovno moč« in »novopridobljeno znanje mi omogoča kakovostnejšo obravnavo pacientov« $(\bar{X}=4,6, s=1,1)$. Najnižje so ocenili strinjanjes trditvama "pozaključkuštudija bom prerazporejen na drugo delovno mesto in »člani zdravstvenega tima me bodo bolj spoštovali, ker bom imel višji strokovni naslov« $(\bar{x}=1,9, s=0,9)$ ter $s$ trditvijo $» z$ znanje se pridobiva samo na delovnem mestu v neposredni praksi« $(\bar{X}=2,1$, $s=1,3)$.

Zaposleni $\mathrm{v}$ bolnišnici so se najbolj strinjali $\mathrm{z}$ naslednjimi trditvami: »znanje je moj intelektualni kapital«, »znanje mi daje strokovno moč« in »z znanjem se krepi profesija zdravstvene nege « $(\bar{X}=4,9, s=0,3)$ ter s trditvami: $» z$ novim znanjem bom uspešnejši pri učenju drugih «, »za svoje delo sem odgovoren «, »izobraževanje je v vseh obdobjih človekovega življenja nujno«, »novo znanje je dodana vrednost « $(\bar{X}=4,8, s=0,4)$. Najmanj so se strinjali z naslednjima trditvama: "po zaključku

Tabela 1: Ocene strinjanja s trditvami po zavodih

Table 1: Assessment of agreement with statements by institution

\begin{tabular}{|c|c|c|c|c|c|c|c|c|c|c|c|c|}
\hline \multirow[t]{2}{*}{$\begin{array}{l}\text { Trditve/ } \\
\text { Statements }\end{array}$} & \multicolumn{4}{|c|}{$\begin{array}{l}\text { Vsi zavodi/ } \\
\text { All institutions }\end{array}$} & \multicolumn{2}{|c|}{$\begin{array}{l}\text { Zdravstveni } \\
\text { dom/ } \\
\text { Health } \\
\text { centre } \\
(n=13)\end{array}$} & \multicolumn{2}{|c|}{$\begin{array}{l}\text { Bolnišnica/ } \\
\text { Hospital } \\
(n=17)\end{array}$} & \multicolumn{2}{|c|}{$\begin{array}{l}\text { Ostalo/ } \\
\text { Others } \\
(n=9)\end{array}$} & \multirow[t]{2}{*}{$F^{\star}$} & \multirow[t]{2}{*}{$p$} \\
\hline & $\bar{X}$ & $s$ & Mo & $\%$ & $\bar{X}$ & $s$ & $\bar{X}$ & $s$ & $\bar{X}$ & $\boldsymbol{s}$ & & \\
\hline $\begin{array}{l}\text { Znanje je moj intelektualni } \\
\text { kapital. }\end{array}$ & 4,7 & 0,9 & 5 & 84,6 & 4,5 & 1,1 & 4,9 & 0,3 & 4,6 & 1,3 & 0,628 & 0,539 \\
\hline Znanje mi daje strokovno moč. & 4,8 & 0,7 & 5 & 87,2 & 4,6 & 1,1 & 4,9 & 0,3 & 4,8 & 0,7 & 0,464 & 0,632 \\
\hline $\begin{array}{l}\text { Z znanjem se krepi profesija } \\
\text { zdravstvene nege. }\end{array}$ & 4,7 & 0,8 & 5 & 87,2 & 4,7 & 1,1 & 4,9 & 0,3 & 4,6 & 1,0 & 0,494 & 0,614 \\
\hline Znanje je vir zaslužka. & 3,5 & 1,0 & 3 & 41,0 & 3,5 & 1,1 & 3,4 & 0,9 & 3,8 & 1,3 & 0,388 & 0,681 \\
\hline $\begin{array}{l}\text { S svojim znanjem pomagam } \\
\text { zavodu doseči organizacijske } \\
\text { cilje. }\end{array}$ & 3,8 & 1,2 & 4 & 35,9 & 3,8 & 1,4 & 3,9 & 0,8 & 3,8 & 1,5 & 0,040 & 0,961 \\
\hline $\begin{array}{l}\text { Znanje je moja največja } \\
\text { vrednota. }\end{array}$ & 4,1 & 0,9 & 4 & 53,8 & 3,9 & 1,0 & 4,2 & 0,6 & 4,0 & 1,2 & 0,289 & 0,751 \\
\hline
\end{tabular}




\begin{tabular}{|c|c|c|c|c|c|c|c|c|c|c|c|c|}
\hline \multirow[t]{2}{*}{$\begin{array}{l}\text { Trditve/ } \\
\text { Statements }\end{array}$} & \multicolumn{4}{|c|}{$\begin{array}{l}\text { Vsi zavodi/ } \\
\text { All institutions }\end{array}$} & \multicolumn{2}{|c|}{$\begin{array}{l}\text { Zdravstveni } \\
\text { dom/ } \\
\text { Health } \\
\text { centre } \\
(n=13) \\
\end{array}$} & \multicolumn{2}{|c|}{$\begin{array}{l}\text { Bolnišnica/ } \\
\text { Hospital } \\
(n=17)\end{array}$} & \multicolumn{2}{|c|}{$\begin{array}{l}\text { Ostalo/ } \\
\text { Others } \\
(n=9)\end{array}$} & \multirow[t]{2}{*}{$F^{\star}$} & \multirow[t]{2}{*}{$p$} \\
\hline & $\overline{\bar{X}}$ & $s$ & Mo & $\%$ & $\overline{\bar{X}}$ & $s$ & $\bar{X}$ & $s$ & $\bar{X}$ & $s$ & & \\
\hline $\begin{array}{l}\text { Novopridobljeno znanje } \\
\text { mi omogoča kakovostnejšo } \\
\text { obravnavo pacientov. }\end{array}$ & 4,5 & 1,1 & 5 & 74,4 & 4,6 & 1,1 & 4,6 & 0,8 & 4,0 & 1,6 & 0,995 & 0,380 \\
\hline $\begin{array}{l}\mathrm{Z} \text { novim znanjem bom } \\
\text { uspešnejši pri učenju drugih. }\end{array}$ & 4,6 & 1,0 & 5 & 76,9 & 4,5 & 1,2 & 4,8 & 0,4 & 4,4 & 1,3 & 0,482 & 0,621 \\
\hline $\begin{array}{l}\text { Znanje je intelektualni kapital } \\
\text { zavoda, v katerem sem zaposlen. }\end{array}$ & 3,8 & 1,2 & 5 & 38,5 & 3,5 & 1,5 & 4,1 & 1,0 & 3,8 & 1,3 & 0,651 & 0,527 \\
\hline $\begin{array}{l}\mathrm{Z} \text { novim znanjem bolje } \\
\text { organiziram lastno delo. }\end{array}$ & 4,1 & 1,1 & 5 & 46,2 & 4,1 & 1,2 & 4,3 & 0,8 & 3,8 & 1,5 & 0,647 & 0,530 \\
\hline $\begin{array}{l}\text { Pridobljeno znanje je osnova za } \\
\text { boljše organiziranje dela drugih. }\end{array}$ & 4,2 & 1,0 & 4 & 43,6 & 4,2 & 1,1 & 4,4 & 0,6 & 3,8 & 1,3 & 0,997 & 0,379 \\
\hline Za svoje delo sem odgovoren. & 4,7 & 0,9 & 5 & 84,6 & 4,7 & 1,1 & 4,8 & 0,4 & 4,4 & 1,3 & 0,484 & 0,620 \\
\hline $\begin{array}{l}\text { Znanje je osnova za } \\
\text { pridobivanje kompetenc. }\end{array}$ & 4,5 & 0,9 & 5 & 71,8 & 4,7 & 1,1 & 4,6 & 0,6 & 4,2 & 1,1 & 0,739 & 0,485 \\
\hline $\begin{array}{l}\text { Izvajam varno zdravstveno nego } \\
\text { ne glede na obseg znanja. }\end{array}$ & 3,9 & 1,3 & 5 & 46,2 & 3,7 & 1,5 & 4,1 & 1,2 & 3,9 & 1,3 & 0,276 & 0,760 \\
\hline $\begin{array}{l}\text { Udeležujem se strokovnih } \\
\text { izpopolnjevanj, ki mi jih plača } \\
\text { organizacija. }\end{array}$ & 4,2 & 1,2 & 5 & 56,4 & 4,3 & 1,2 & 4,3 & 1,0 & 3,9 & 1,5 & 0,396 & 0,676 \\
\hline $\begin{array}{l}\text { Izobraževanje je v vseh } \\
\text { obdobjih človekovega življenja } \\
\text { nujno. }\end{array}$ & 4,6 & 0,9 & 5 & 79,5 & 4,5 & 1,1 & 4,8 & 0,4 & 4,6 & 1,3 & 0,256 & 0,775 \\
\hline $\begin{array}{l}\text { Višja kot je stopnja izobrazbe, } \\
\text { boljši so rezultati obravnave } \\
\text { pacienta. }\end{array}$ & 3,8 & 1,1 & 4 & 43,6 & 3,9 & 1,4 & 3,9 & 0,9 & 3,7 & 1,3 & 0,144 & 0,866 \\
\hline $\begin{array}{l}\text { Teoretično znanje je } \\
\text { pomembno. }\end{array}$ & 4,3 & 1,0 & 5 & 53,8 & 4,3 & 1,3 & 4,3 & 0,7 & 4,2 & 1,1 & 0,022 & 0,979 \\
\hline Paciente obravnavam varno. & 4,5 & 1,0 & 5 & 66,7 & 4,5 & 1,1 & 4,7 & 0,5 & 4,1 & 1,4 & 1,120 & 0,337 \\
\hline $\begin{array}{l}\text { Udeležbo na strokovnih } \\
\text { izpopolnjevanjih si plačam sam. }\end{array}$ & 3,1 & 1,6 & $\begin{array}{l}1 \text { in } \\
5\end{array}$ & 28,2 & 3,5 & 1,6 & 2,9 & 1,7 & 3,0 & 1,6 & 0,492 & 0,616 \\
\hline $\begin{array}{l}\text { Zavod podpira izobraževanje } \\
\text { zaposlenih. }\end{array}$ & 3,5 & 1,3 & 5 & 28,2 & 3,3 & 1,3 & 3,5 & 1,3 & 3,9 & 1,1 & 0,559 & 0,576 \\
\hline $\begin{array}{l}\text { Zavod lahko umestim med } \\
\text { učeče se organizacije. }\end{array}$ & 3,7 & 1,3 & 5 & 41,0 & 3,3 & 1,5 & 4,1 & 1,0 & 3,7 & 1,5 & 1,221 & 0,307 \\
\hline $\begin{array}{l}\text { Zavod ima izdelan letni } \\
\text { načrt internega strokovnega } \\
\text { izpopolnjevanja. }\end{array}$ & 3,4 & 1,1 & 3 & 38,5 & 2,7 & 1,0 & 3,8 & 1,0 & 3,4 & 1,2 & 4,339 & 0,021 \\
\hline $\begin{array}{l}\text { Pri obravnavi pacienta je } \\
\text { najpomembnejša praktična } \\
\text { usposobljenost. }\end{array}$ & 3,8 & 1,1 & 4 & 38,5 & 3,4 & 1,4 & 3,9 & 0,9 & 4,1 & 1,1 & 1,314 & 0,281 \\
\hline $\begin{array}{l}\text { Z izobraževanjem pridobivam } \\
\text { koristno znanje za svoje delo. }\end{array}$ & 4,4 & 1,0 & 5 & 61,5 & 4,3 & 1,2 & 4,6 & 0,5 & 4,2 & 1,4 & 0,491 & 0,616 \\
\hline $\begin{array}{l}\text { Za organizacijo je pomembno, } \\
\text { da imam več znanja. }\end{array}$ & 3,9 & 1,2 & 5 & 43,6 & 3,7 & 1,5 & 4,2 & 0,9 & 3,9 & 1,4 & 0,567 & 0,572 \\
\hline $\begin{array}{l}\text { Za organizacijo je pomembno, } \\
\text { da sem usposobljen za delo na } \\
\text { različnih področjih zdravstvene } \\
\text { nege. }\end{array}$ & 3,9 & 1,3 & 5 & 43,6 & 3,8 & 1,6 & 4,2 & 0,9 & 3,6 & 1,4 & 0,735 & 0,487 \\
\hline $\begin{array}{l}\text { Znanje se pridobiva samo na } \\
\text { delovnem mestu v neposredni } \\
\text { praksi. }\end{array}$ & 2,3 & 1,3 & 1 & 33,3 & 2,1 & 1,3 & 2,5 & 1,3 & 2,4 & 1,4 & 0,365 & 0,697 \\
\hline $\begin{array}{l}\text { Znanje organizacije ponazorimo } \\
\text { s pojmom intelektualni kapital. }\end{array}$ & 3,8 & 1,3 & 5 & 53,9 & 3,8 & 1,3 & 3,9 & 0,9 & 3,6 & 2,0 & 0,186 & 0,831 \\
\hline $\begin{array}{l}\text { Človeški kapital vključuje } \\
\text { kompetence posameznika. }\end{array}$ & 4,1 & 1,0 & 4 & 43,6 & 3,8 & 1,1 & 4,2 & 0,8 & 4,1 & 1,3 & 0,411 & 0,666 \\
\hline
\end{tabular}




\begin{tabular}{|c|c|c|c|c|c|c|c|c|c|c|c|c|}
\hline \multirow[t]{2}{*}{$\begin{array}{l}\text { Trditve/ } \\
\text { Statements }\end{array}$} & \multicolumn{4}{|c|}{$\begin{array}{l}\text { Vsi zavodi/ } \\
\text { All institutions }\end{array}$} & \multicolumn{2}{|c|}{$\begin{array}{l}\text { Zdravstveni } \\
\text { dom/ } \\
\text { Health } \\
\text { centre } \\
(n=13)\end{array}$} & \multicolumn{2}{|c|}{$\begin{array}{l}\text { Bolnišnica/ } \\
\text { Hospital } \\
(n=17)\end{array}$} & \multicolumn{2}{|c|}{$\begin{array}{l}\text { Ostalo/ } \\
\text { Others } \\
(n=9)\end{array}$} & \multirow[t]{2}{*}{$F^{\star}$} & \multirow[t]{2}{*}{$p$} \\
\hline & $\bar{X}$ & $s$ & Mo & $\%$ & $\overline{\bar{X}}$ & $s$ & $\bar{X}$ & $s$ & $\bar{X}$ & $s$ & & \\
\hline $\begin{array}{l}\text { Pacient je zadovoljen, ker imam } \\
\text { veliko znanja. }\end{array}$ & 4,0 & 1,1 & 5 & 46,2 & 4,2 & 1,3 & 4,1 & 1,0 & 3,8 & 1,2 & 0,293 & 0,748 \\
\hline $\begin{array}{l}\text { Zavedam se pomena svojega } \\
\text { znanja. }\end{array}$ & 4,3 & 1,1 & 5 & 59,0 & 4,2 & 1,5 & 4,4 & 0,6 & 4,3 & 1,3 & 0,187 & 0,830 \\
\hline $\begin{array}{l}\text { Nadrejeni vedo, da bom naredil } \\
\text { manj napak pri svojem delu, ker } \\
\text { sem pridobil novo znanje. }\end{array}$ & 3,5 & 1,1 & 3 & 33,3 & 3,4 & 1,0 & 3,5 & 1,1 & 3,8 & 1,3 & 0,351 & 0,706 \\
\hline $\begin{array}{l}\text { Pri delu sem samozavesten, } \\
\text { ker sem opolnomočen z novim } \\
\text { znanjem. }\end{array}$ & 4,2 & 1,1 & 5 & 51,3 & 4,2 & 1,2 & 4,2 & 0,8 & 4,0 & 1,4 & 0,157 & 0,856 \\
\hline $\begin{array}{l}\text { Člani zdravstvenega tima me } \\
\text { bodo bolj spoštovali, ker bom } \\
\text { imel višji strokovni naslov. }\end{array}$ & 2,6 & 1,2 & 3 & 30,8 & 1,9 & 0,9 & 2,7 & 1,4 & 3,4 & 0,7 & 5,059 & 0,012 \\
\hline $\begin{array}{l}\text { Vodstvo spodbuja zaposlene } \mathrm{k} \\
\text { pridobivanju novega znanja. }\end{array}$ & 3,4 & 1,3 & 5 & 25,6 & 3,0 & 1,4 & 3,2 & 1,3 & 4,1 & 1,1 & 2,110 & 0,136 \\
\hline $\begin{array}{l}\text { Novo znanje je dodana } \\
\text { vrednost. }\end{array}$ & 4,6 & 0,9 & 5 & 79,5 & 4,5 & 1,1 & 4,8 & 0,4 & 4,4 & 1,3 & 0,592 & 0,558 \\
\hline $\begin{array}{l}\text { Moje izobraževanje je v skladu } \\
\text { s kadrovskim načrtom razvoja }\end{array}$ & 2,9 & 1,6 & 1 & 28,2 & 2,8 & 1,8 & 2,9 & 1,5 & 3,0 & 1,5 & 0,025 & 0,975 \\
\hline
\end{tabular}

s kadrovskim načrtom razvoja zaposlenih.

Legenda/Legend: $n$-število/number; $\bar{X}$ - povprečna vrednost/average; $s$ - standardni odklon/standard deviation; $F^{*}-$ enofaktorska analiza variance/single factor analysis of variance; $p$ - statistično pomembna razlika/statistically significant difference

študija bom prerazporejen na drugo delovno mesto « $(\bar{X}$ $=2,1, s=1,2)$ in "znanje se pridobiva samo na delovnem mestu v neposredni praksi« $(\bar{X}=2,5, s=1,3)$.

Zaposleni v drugih zavodih so se najbolj strinjali s trditvami »znanje mi daje strokovno moč $«(\bar{X}=4,8, s=0,7)$ in $\mathrm{z}$ naslednjimi trditvami: »znanje je moj intelektualni kapital«, »Z znanjem se krepi profesija zdravstvene nege« in »izobraževanje je v vseh obdobjih človekovega življenja nujno« $(\bar{X}=4,6)$. Najmanj so se strinjali s trditvama "po zaključku študija bom prerazporejen na drugo delovno mesto « $(\bar{X}=2,3, s=1,1)$ in "znanje se pridobiva samo na delovnem mestu v neposredni praksi $«(\bar{X}=2,4, s=1,4)$.

Tabela 2: Najvišje in najnižje strinjanje s trditvami z ozirom na zavod Table 2: The highest and lowest levels of agreement by institution

\begin{tabular}{|c|c|c|}
\hline $\begin{array}{l}\text { Zavod/ } \\
\text { Institution }\end{array}$ & $\begin{array}{l}\text { Najvišje strinjanje } s \text { trditvijo/ } \\
\text { The highest agreeing with the statements }\end{array}$ & $\begin{array}{l}\text { Najnižje strinjanje } s \text { trditvijo/ } \\
\text { The lowest agreeing with the statements }\end{array}$ \\
\hline Zdravstveni dom & $\begin{array}{l}\text { - z znanjem se krepi profesija zdravstvene nege } \\
\text { - za svoje delo sem odgovoren } \\
\text { - znanje je osnova za pridobivanje kompetenc } \\
\text { - znanje mi daje strokovno moč } \\
\text { - novopridobljeno znanje mi omogoča } \\
\text { kakovostnejšo obravnavo pacientov }\end{array}$ & $\begin{array}{l}\text { - po zaključku študija bom prerazporejen na } \\
\text { drugo delovno mesto } \\
\text { - člani tima me bodo bolj spoštovali, ker bom } \\
\text { imel višji naziv } \\
\text { - znanje se pridobiva samo na delovnem mestu } \\
\text { v neposredni praksi }\end{array}$ \\
\hline Bolnišnica & $\begin{array}{l}\text { - znanje je moj intelektualni kapital } \\
\text { - znanje mi daje strokovno moč } \\
\text { - z znanjem se krepi profesija zdravstvene nege } \\
\text { - z novim znanjem bom uspešnejši pri učenju } \\
\text { drugih } \\
\text { - za svoje delo sem odgovoren } \\
\text { - izobraževanje je v vseh obdobjih človekovega } \\
\text { življenja nujno } \\
\text { - novo znanje je dodana vrednost }\end{array}$ & $\begin{array}{l}\text { - po zaključku študija bom prerazporejen na } \\
\text { drugo delovno mesto } \\
\text { - znanje se pridobiva samo na delovnem mestu } \\
\text { v neposredni praksi }\end{array}$ \\
\hline Ostalo & $\begin{array}{l}\text { - znanje mi daje strokovno moč } \\
\text { - znanje je moj intelektualni kapital } \\
\text { - z znanjem se krepi profesija zdravstvene nege } \\
\text { - izobraževanje je v vseh obdobjih človekovega } \\
\text { življenja nujno }\end{array}$ & $\begin{array}{l}\text { - po zaključku študija bom prerazporejen na } \\
\text { drugo delovno mesto } \\
\text { - znanje se pridobiva samo na delovnem mestu } \\
\text { v neposredni praksi }\end{array}$ \\
\hline
\end{tabular}


Tabela 3: Korelacijska matrika med kategorijami: znanje, kompetence, odgovornost, varnost, družbena pomembnost Table 3: Correlation matrix between categories: knowledge, competence, responsibility, safety, social importance

\begin{tabular}{|c|c|c|c|c|c|c|}
\hline $\begin{array}{l}\text { Kategorije/ } \\
\text { Categories }\end{array}$ & & $\begin{array}{l}\text { Znanje/ } \\
\text { Knowledge }\end{array}$ & $\begin{array}{l}\text { Kompetence/ } \\
\text { Competences }\end{array}$ & $\begin{array}{l}\text { Odgovornost/ } \\
\text { Responsibility }\end{array}$ & $\begin{array}{l}\text { Varnost/ } \\
\text { Safety }\end{array}$ & $\begin{array}{l}\text { Družbena } \\
\text { pomembnost/ } \\
\text { Social } \\
\text { importance }\end{array}$ \\
\hline \multirow[t]{2}{*}{ znanje } & $r^{*}$ & 1 & 0,829 & 0,927 & 0,739 & 0,843 \\
\hline & $p$ & & $<0,001$ & $<0,001$ & $<0,001$ & $<0,001$ \\
\hline \multirow[t]{2}{*}{ kompetence } & $r^{*}$ & & 1 & 0,799 & 0,649 & 0,859 \\
\hline & $p$ & & & $<0,001$ & $<0,001$ & $<0,001$ \\
\hline \multirow[t]{2}{*}{ odgovornost } & $r^{*}$ & & & 1 & 0,710 & 0,850 \\
\hline & $p$ & & & & $<0,001$ & $<0,001$ \\
\hline \multirow[t]{2}{*}{ varnost } & $r^{*}$ & & & & 1 & 0,710 \\
\hline & $p$ & & & & & $<0,001$ \\
\hline \multirow[t]{2}{*}{ družbena pomembnost } & $r^{*}$ & & & & & 1 \\
\hline & $p$ & & & & & \\
\hline
\end{tabular}

Legenda/Legend: $r^{\star}$ - Pearsonov korelacijski koeficient/Pearson's coefficient of correlation; $p$ - statistično pomembna razlika/ statistically significant difference

Z ozirom na vrsto zavoda je statistično pomembna razlika pri trditvi »zavod ima izdelan letni načrt internega strokovnega izpopolnjevanja « $\left(p=0,021, F^{\star}=4,339\right)$, pri čemer so večje povprečje strinjanja navedli zaposleni $\mathrm{v}$ bolnišnici $(\bar{x}=3,8)$, nato $\mathrm{v}$ drugih zavodih $(\bar{x}=3,4)$ in najmanjše strinjanje $\mathrm{v}$ zdravstvenem domu $(\bar{X}=2,7)$. Statistično pomembna razlika je tudi pri trditvi »člani zdravstvenega tima me bodo bolj spoštovali, ker bom imel višji naziv« ( $\left.p=0,012, F^{\star}=5,059\right)$; s tem se najbolj strinjajo zaposleni $\mathrm{v}$ drugih zavodih $(\bar{x}=3,4)$, sledijo zaposleni v bolnišnici $(\bar{X}=2,7)$ in nato $\mathrm{v}$ zdravstvenem $\operatorname{domu}(\bar{X}=1,9)$.

V Tabeli 2 smo navedli trditve, ki so bile ocenjene $z$ dvema najvišjima in dvema najnižjima povprečnima vrednostima.

V vseh zavodih (zdravstveni dom, bolnišnica, ostalo) se najbolj strinjajo s trditvama "znanje mi daje strokovno moč« in "Z znanjem se krepi profesija zdravstvene nege" in najmanj strinjajo s trditvama "po zaključku študija bom prerazporejen na drugo delovno mesto" in "znanje se pridobiva samo na delovnem mestu v neposredni praksi«.

Po oceni vsebine posamezne trditve smo le-te združili v kategorije: znanje, kompetence, odgovornost, varnost in družbena pomembnost. Korelacijska matrika (Tabela 3) je pokazala, da so med vsemi kategorijami močne pozitivne korelacije $(r \geq 0,7)$ razen med kategorijama "kompetence" in "varnost", ko gre za srednje močno pozitivno korelacijo $(r \geq 0,3-r \leq 0,7)$.

\section{Diskusija}

Raziskava je pokazala, da se anketirani ne glede na mesto zaposlitve zavedajo, da jim znanje daje strokovno moč in da se z znanjem krepi profesija zdravstvene nege. Bradbury-Jones in sodelavci (2008) so proučevali moč v zdravstveni negi ter ugotovili, da je le-ta osrednjega pomena za razumevanje zdravstvene nege in da je potrebno razumeti delovanje moči znotraj določenega družbenega konteksta. Ugotovili so tudi tesno povezavo med močjo in znanjem, ki lahko opolnomočita ne le posameznika temveč tudi profesijo zdravstvene nege. Leppänen (2010) je proučevala strokovno moč medicinskih sester $\mathrm{v}$ interakciji s pacienti $\mathrm{v}$ specifičnem okolju telefonskih klicev pacientov. Poudarja pomen strokovne moči (znanja) medicinskih sester, saj se medicinske sestre pri telefonskih klicih pacientov odločajo, katera vprašanja bodo postavile, ugotavljajo zdravstvene probleme pacientov in odločajo, kateri nasvet bodo posredovale oziroma odločajo o nujnosti nadaljnje obravnave pacienta. Komatsu in Yagasaki (2014) sta s kvalitativno raziskavo štirih fokusnih skupin, $v$ katerih je sodelovalo 21 medicinskih sester, identificirala moč zdravstvene nege na treh področjih: povezovanje s pacienti, osebna koordinacija in uresničevanje pacientovih potencialov. $\mathrm{Na}$ osnovi rezultatov raziskave sta zaključila, da je moč medicinskih sester $\mathrm{v}$ njihovi edinstveni vlogi, na osnovi katere se lahko gradi strokovna identiteta medicinskih sester ter krepi njihova vidnost $\mathrm{v}$ multidisciplinarnem okolju.

Anketirani $\mathrm{v}$ zdravstvenem domu in $\mathrm{v}$ bolnišnici, $\mathrm{v}$ primerjavi $\mathrm{z}$ zaposlenimi $\mathrm{v}$ ostalih zavodih, menijo, da so za svoje delo odgovorni. Etično, strokovno, kazensko in materialno odgovornost za delo jim predpisuje Zakon o zdravstveni dejavnosti (ZZDej) (2005). Painter (2010) navaja, da so medicinske sestre odgovorne za oskrbo, ki jo izvajajo, in za izboljšanje kakovosti prakse zdravstvene nege. Avtorica tudi navaja rezultate študije, da kar 38,6 \% medicinskih sester, ki so zaključile študij, ni usposobljenih za izboljševanje kakovosti. Tudi Wyatt (2012) meni, da so medicinske sestre odgovorne za kakovost zdravstvene nege in da morajo doseči čim višjo stopnjo izobrazbe, da bi z novim znanjem "stopile iz sence" drugih disciplin v zdravstvu. Ramšak Pajk (2011) je zapisala, da prevzemanje odgovornosti pomeni tudi avtonomno in neodvisno 
delovanje zdravstvene nege in medicinskih sester in da je pot do priznavanja stroke tesno povezana $\mathrm{z}$ znanjem. Faseleh-Jahromi in sodelavci (2014) so proučevali družbeno odgovornost medicinskih sester. V raziskavo so vključili deset medicinskih sester $\mathrm{z}$ različnih delovnih mest in izvedli polstrukturirane intervjuje. Ugotovili so, da morajo imeti medicinske sestre, ki so družbeno odgovorne, pozitivne osebnostne značilnosti (pozitivne človeške lastnosti, kompetence, vrednote, usmerjenost $\mathrm{k}$ rezultatom, strokovna uspešnost) ter tudi potrebna znanja za izvajanje nalog.

Anketirani $\mathrm{v}$ bolnišnici in $\mathrm{v}$ ostalih zavodih (socialnovarstveni zavod, zasebnik, izven zdravstva) menijo, da je izobraževanje v vseh obdobjih človekovega življenja nujno. Skela-Savič (2010) ugotavlja, da je potrebno znanja nadgrajevati v okviru vseživljenjskega in poklicnega učenja, saj se mora proces obravnave pacienta odvijati kot integracija znanj, dokazov in veščin, ki jih zaposleni nenehno razvijajo.

Anketirani ne glede na mesto zaposlitve menijo, da po zaključku študija ne bodo prerazporejeni na drugo delovno mesto, čeprav bi morali svoje novo znanje uporabiti kot dodano vrednost, s katero se dosegajo načrtovani cilji organizacije. Zdravstveni zavodi bodo namreč zaradi zmanjšanja finančnih virov morali svoje poslovanje racionalizirati tudi na račun kadrov (Bregar, 2013), kar pomeni zmanjševanje števila medicinskih sester in zdravstvenih tehnikov in nižanje stopnje izobrazbe (Klemenc, 2013). Tako ne moremo govoriti o menedžmentu znanja, saj zavodi $\mathrm{z}$ novim znanjem ne ravnajo kot $\mathrm{z}$ redko dobrino (Možina, 2006), pa tudi zavedajo se ne, da je znanje organizacije večje, kot je vsota znanj posameznikov, saj je znanje organizacije intelektualni kapital, kar je seveda mnogo več. Pajnkihar (2011) meni, da višja kot je stopnja izobrazbe v praksi, boljši so rezultati v obravnavi pacientov in učinkovitejši je zdravstveni sistem oz. cenejše je zdravstvo, kar so tudi dokazali Spence Laschinger in sodelavci (2014) v raziskavi, ki je vključila 525 medicinskih sester iz 49 oddelkov v 25 akutnih bolnišnicah.

Anketirani v vseh zavodih se zavedajo, da se znanje ne pridobiva samo na delovnem mestu $\mathrm{v}$ neposredni praksi. To se sklada s trditvami Filej (2010), da "poklic medicinske sestre zahteva teoretično znanje in praktične izkušnje«. Avtorica tudi poudarja, da je za učinkovito izvajanje zdravstvene nege ključna čim večja povezanost teorije in prakse. Sochan (2011) primerljivo navaja, da sta teoretično in praktično znanje osnova znanja zdravstvene nege. Christensen (2011) je proučeval povezavo teoretičnega in praktičnega znanja in ugotovil, da je integracija teoretičnega in praktičnega znanja temelj sodobne zdravstvene nege. Za izvajanje sodobne zdravstvene nege pa mora medicinska sestra imeti strokovno znanje, sposobnost odločanja in kompetence. McCurry in sodelavci (2010) so ugotovili, da je profesija zdravstvene nege dolžna družbi zagotavljati na znanju temelječo prakso in da je integracija teorije in prakse osnova za doseganje ciljev. Ko bo zdravstvena nega dosegla sintezo teorije in prakse, bo zdravstvena nega dosegla družbeno in moralno sprejetje.

Raziskava je tudi pokazala, da ima večina bolnišnic izdelan letni načrt internega strokovnega izpopolnjevanja. Zaposleni so najpomembnejše premoženje in niso le strošek, ki ga je potrebno zmanjšati, res pa je, kot navaja Brumen (2010), problem poslovanja zdravstvenih zavodov obvladovanje naraščajočih stroškov. Mnogi zavodi so se zato odločili za organiziranje internih strokovnih izpopolnjevanj, kar izvajalcem zdravstvene nege daje možnost, da se jih udeležijo $\mathrm{v}$ večjem številu. V avstralski raziskavi, ki je zajela 289 medicinskih sester in babic, zaposlenih $\mathrm{v}$ javnih in zasebnih bolnišnicah, in katere namen je bil proučili možnosti njihovega kontinuiranega strokovnega razvoja, so raziskovalci ugotovili izreden pomen podpore menedžmenta. Dve tretjini sodelujočih $\mathrm{v}$ raziskavi sta namreč mnenja, da je kontinuiran strokovni razvoj potreben, vendar so zaradi pomanjkanja kadra izrazili zaskrbljenost glede možnosti, da bi izobraževanje potekalo med delovnim časom (Katsikitis, et al., 2013).

Zaposleni v drugih zavodih (zasebnik, socialnovarstveni zavod, izven zdravstva) so prepričani, da jih bodo člani zdravstvenega tima bolj spoštovali, ko bodo imeli višji naziv - magister/magistrica vzgoje in menedžmenta $\mathrm{v}$ zdravstvu. Pojavlja se vprašanje, zakaj je to mnenje prisotno le pri zasebnikih in v socialnovarstvenih zavodih, in ne tudi v bolnišnicah in zdravstvenih domovih. Morda zato, ker gre $\mathrm{v}$ bolnišnicah in zdravstvenih domovih za večpoklicno timsko delo in so praviloma člani tima enaki med enakimi, pri zasebnikih in $\mathrm{v}$ socialnovarstvenih zavodih pa gre za bolj individualno delo vsakega posameznega zdravstvenega strokovnjaka in za odnos lastnik - zasebnik in zaposleni. Menedžerji, kot navaja Robida (2009), pa lahko timsko delo tudi zavirajo.

Kot smo ugotovili $\mathrm{z}$ raziskavo, je torej po mnenju študentov znanje močno povezano $s$ kompetencami, odgovornostjo, varnostjo in družbeno pomembnostjo stroke zdravstvene nege.

Skela-Savič in Robida (2012) navajata, da imata kakovost in varnost zdravstvene obravnave velik vpliv na izide zdravljenja, ter povzemata nekatere avtorje, ki trdijo, da današnja zdravstvena obravnava ni varna in da prepogosto ni osnovana na znanstvenih dokazih. Navajata tudi, da je raziskava, ki je bila izvedena $\mathrm{v}$ sedemindvajsetih slovenskih bolnišnicah, pokazala, da manjka sistematični pristop $\mathrm{k}$ razvoju kakovosti in varnosti zdravstvene oskrbe pacientov.

Kompetenten posameznik je praviloma tisti, ki ima zadosten obseg znanja in spretnosti in jih zna uspešno integrirati, tako da učinkovito opravlja svoje delo (Železnik \& Filej, 2010). Ne glede na to, pri kateri delitvi ali definiciji začnemo, je pomembno, da se $\mathrm{v}$ praksi ukvarjamo z bistvom pojma »biti kompetenten" (izpolniti zahteve dela) in ne toliko $\mathrm{z}$ vprašanjem »imeti kompetenco « (posedovati potrebne osebne značilnosti za kompetentno delo) (Dekleva, et al., 2006). Robinson Wolf (2012) navaja, da medicinske sestre izvajajo zdravstveno 
nego pri pacientu s strokovno odgovornostjo in v skladu z etičnim kodeksom obnašanja. Peršolja Černe (2012) pa meni, da se profesija razvija s sistematičnim pridobivanjem znanja in s praktično uporabo znanstveno pridobljenih izsledkov. Kot ugotavljata Popović in Pahor (2011), se družbena pomembnost stroke kaže tudi v medijih, ki so pomemben vir informacij o medicinskih sestrah in njihovem delu. Avtorici v svoji raziskavi ugotavljata, da so bile medicinske sestre pozitivno predstavljene $\mathrm{v}$ tistih časopisnih besedilih, ki predstavljajo (tudi) sodobno zdravstveno nego. Bregar in Skela-Savič (2013) pa ugotavljata, da zdravstvena nega $\mathrm{v}$ družbi ni prepoznana kot znanstvena disciplina in da je potrebno povečati vlogo izobraževalnih institucij in vpliv prepoznavnih posameznikov $\mathrm{v}$ zdravstveni negi, ki morajo $\mathrm{v}$ javnosti predstaviti zdravstveno nego.

\section{Zaključek}

Težnje medicinskih sester $\mathrm{v}$ slovenskem prostoru so že več let usmerjene $\mathrm{k}$ samostojnosti in odgovornosti za lastno delo ter $\mathrm{k}$ večji prepoznavnosti zdravstvene nege $\mathrm{v}$ družbi. Da bi lahko to dosegle, potrebujejo znanje, ki je osnova sodobne zdravstvene nege. Pridobivanje znanja poteka na različne načine, od formalnega, neformalnega, kontinuiranega, do pridobivanja znanja neposredno v delovnem procesu. Študenti magistrskega študija se zavedajo, da jim znanje daje strokovno moč in da se $s$ pomočjo znanja lahko okrepi profesija zdravstvene nege in $\mathrm{s}$ tem posledično tudi njihov položaj $\mathrm{v}$ družbi. Istočasno se zavedajo, da svojega znanja ne bodo mogli v celoti uporabiti v zavodu, kjer so zaposleni, saj ne bodo prerazporejeni na delovna mesta, ki bi bila ustrezna njihovi stopnji izobrazbe in njihovemu novemu znanju. Zavodi zaradi krize žal ne razvijajo novih delovnih mest ter s tem izgubljajo svoj intelektualni potencial, ki bi v kriznem času lahko učinkovito pripomogel tudi $\mathrm{k}$ doseganju ciljev zavoda.

Zavedamo se, da dobljenih rezultatov ni možno posploševati in da je naložba vsakega posameznika $\mathrm{v}$ pridobivanje novega znanja na magistrski stopnji študija pravzaprav njihova naložba za prihodnost. Prav tako z zanesljivostjo ne moremo trditi, kaj so anketiranci imeli v mislih, ko so odgovorili, da ne bodo prerazporejeni na drugo delovno mesto. Zaposleni se vse premalo zavedajo pomena horizontalnega kariernega napredovanja (večja strokovnost) in težijo bolj $\mathrm{k}$ vertikalnemu kariernemu napredovanju na vodilna in vodstvena delovna mesta, za katera pa ni jasnih kriterijev glede stopnje izobrazbe.

Največ koristi od novopridobljenega znanja študentov magistrskega študijskega programa bodo $\mathrm{v}$ tem trenutku imeli pacienti, ki bodo kakovostneje in bolj varno obravnavani, s čimer je dosežen vsaj eden izmed ciljev izobraževanja na magistrski stopnji. Z gotovostjo pa lahko trdimo, da bodo s svojim novim znanjem diplomanti doprinesli $\mathrm{k}$ profesionalizaciji zdravstvene nege, saj se z raziskovanjem posledično veča baza znanja, ki pomembno prispeva k razvoju stroke.

\section{Literatura}

Angelmar, R. \& Berman, P.C., 2007. Patient empowerment and efficient health outcomes. In: The Steering Group: Financing sustainable healthcare in Europe: new approaches for new outcomes. Conclusions from a collaborative investigation into contentions areas of healthcare, pp. 139-163. Available at: http://www.sitra.fi/julkaisut/muut/the cox report.pdf\#page = $\underline{139}[15.10 .2014]$.

Bradbury-Jones, C., Sambrook, S., Irvine, F., 2008. Power and empowerment in nursing: a fourth theoretical approach. Journal of Advanced Nursing, 62(2), pp. 258-265.

http://dx.doi.org/10.1111/j.1365-2648.2008.04598.x

PMid:18394038

Bregar, B., 2013. Zdravstvena nega v pričakovanju reform. Obzornik zdravstvene nege, 47(2), pp. 132-134.

Bregar, B. \& Skela-Savič, B., 2013. Pomen vključevanja zaposlenih v zdravstveni negi pri obvladovanju politike zdravstvenega sistema. Obzornik zdravstvene nege, 47(1), pp. 18-27.

Brumen, M., 2010. Tudi zdravstvena nega se sooča z izzivi gospodarske krize. Obzornik zdravstvene nege, 44(2), pp. 69-70.

Cardoso, A. \& Paiva e Silva, A., 2010. Representing nursing knowledge on maternal and neonatal health: a study on the cultural suitability of ICNP. International Nursing Review, 57(4), pp. 426-434.

http://dx.doi.org/10.1111/j.1466-7657.2010.00829.x

PMid:21050193

Christensen, M., 2011. Advancing nursing practice: redefining the theoretical and practical Integration of knowledge. Journal of Clinical Nursing, 20(5-6), pp. 873-881.

http://dx.doi.org/10.1111/j.1365-2702.2010.03392.x

PMid:21320209

Dekleva, B., Kobolt, A. \& Klemenčič, M.M., 2006. Analiza doseženih in zaželenih kompetenc študijskega programa Socialna pedagogika na Pedagoški fakulteti v Ljubljani. In: Tancig, S. \& Devjak, T. eds. Prispevki k posodobitvi pedagoških študijskih programov. Ljubljana: Pedagoška fakulteta Univerze v Ljubljani, pp. 150-170.

Faseleh-Jahromi, M., Moattari, M. \& Peyrovi, H., 2014. Iranian nurses' perceptions of social responsibility: a qualitative study. Nursing Ethics, 21(3), pp. 289-298.

http://dx.doi.org/10.1177/0969733013495223

PMid:24036668

Filej, B., 2010. Pomen povezovanja teorije in prakse v zdravstveni negi. In: Skela-Savič, B., et al. eds. Teoretične in praktične osnove zdravstvene nege. Jesenice: Visoka šola za zdravstveno nego, pp. 103-106. 
Fink, T., 2006. Trimo - učeča se organizacija. In: Možina, S. \& Kovač, J. eds. Menedžment znanja. Maribor: Založba Pivec, pp. 283-290.

Gerrish, K. \& Lacey, A., eds. 2010. The research process in nursing. 6th ed. Chichester: Wiley-Blackwell, pp. 3-13.

Gruban, B., 2004. Uvajanje modelov kompetenc: prenove kadrovskih sistemov. Kakovost, (1), pp. 2-6.

Hajdinjak, G. \& Meglič, R., 2006. Sodobna zdravstvena nega. Ljubljana: Univerza v Ljubljani, Visoka šola za zdravstvo, pp. $171-180$

Hicks, N.A. \& Butkus, S.E., 2011. Knowledge development for master teachers. Journal of Theory Construction \& Testing, 15(2), pp. 32-35.

Katsikitis, M., McAllister, M., Sharman, R., Raith, L., FaithfullByrne, A. \& Priaulx, R., 2013. Continuing professional development in nursing in Australia: current awareness, practice and future directions. Contemporary Nurse, 45(1), pp. 33-45. http://dx.doi.org/10.5172/conu.2013.45.1.33 PMid:24099224

Klemenc, D., 2013. Nagovor na slavnostni akademiji ob mednarodnem dnevu medicinskih sester in mednarodnem dnevu babic 10. 5. 2013, Brdo pri Kranju. Utrip, 21(5), pp. 4-5.

Komatsu, H. \& Yagasaki, K., 2014. The power of nursing: guiding patients through a journey of uncertainty. European Journal of Oncology Nursing, 18(4), pp. 419-424. http://dx.doi.org/10.1016/j.ejon.2014.03.006 PMid:24721178

Leppänen, V., 2010. Power in telephone-advice nursing. Nursing Inquiry, 17(1), pp. 14-25. http://dx.doi.org/10.1111/j.1440-1800.2009.00480.x PMid:20137027

Manojlovich, M., 2007. Power and empowerement in nursing: looking backward to inform the future. Online Journal of Issues In Nursing, 12(1), p. 2.

PMid:17330984

McAllisster, H., Dunn, G., Payne, K., Davies, L. \& Todd, C., 2012. Patient empowerment: the need to consider it as a measurable patient-reported outcome for chronic conditions. BMC Health Services Research, 12(1), pp. 157-164.

McCurry, M.K., Revell, S.M. \& Roy, S.C., 2010. Knowledge for the good of the individual and society: linking philosophy, disciplinary goals, theory, and practice. Nursing Philosophy, 11(1), pp. 42-52. http://dx.doi.org/10.1111/j.1466-769X.2009.00423.x PMid:20017882
Millard, L., Hallett, C. \& Luker, K., 2006. Nurse-patient interaction and decision-making in care: patient involvement in community nursing. Journal of Advanced Nursing, 55(2), pp. $142-150$

http://dx.doi.org/10.1111/j.1365-2648.2006.03904.x

PMid:16866806

Možina, S. 2006. Vloga menedžmenta znanja v organizaciji. In: Možina, S. \& Kovač, J., eds. Menedžment znanja. Maribor: Založba Pivec, pp. 127-151.

Painter, D.R., 2010. Nurses responsibility to improve practice. Nephrology Nursing Journal, 37(3), p. 227.

PMid:20629461

Pajnkihar. M., 2011. Teorija v praksi zdravstvene nege. Utrip, 19(2), pp. 4-5.

Parahoo, K. 2006. Nursing research: principles, process and issues. 2nd ed. London: Palgrave-Macmillan, pp. 4-44.

Peršolja Černe, M., 2012. Med prakso in teorijo znanje nima lastnika. Obzornik zdravstvene nege, 46(4), pp. 273-274.

Popović, P. \& Pahor, M., 2011. Javna podoba medicinskih sester v Sloveniji: analiza objav v časniku Delo. Obzornik zdravstvene nege, 45(4), pp. 239-245.

Ramšak Pajk, J., 2011. Znanje - temelj zdravstvene nege. Obzornik zdravstvene nege, 45(4), pp. 237-238.

Rao, A., 2012. The contemporary construction of nurse empowerment. Journal of Nursing Scholarship, 44(4), pp. 396-402.

http://dx.doi.org/10.1111/j.1547-5069.2012.01473.x

PMid:23062275

Robida, A., 2009. Pot do odlične zdravstvene prakse. Ljubljana: Planet GV, p. 56

Robinson Wolf, Z., 2012. Nursing practice breakdowns: good and bad nursing. Medsurg Nursing, 21(1), pp. 16-22. PMid:22479870

Sitar, A.S., 2006. Oblike in razsežnosti znanja v organizaciji. In: Možina, S. \& Kovač, J., eds. Menedžment znanja. Maribor: Založba Pivec, pp. 55-69.

Skela-Savič, B., 2010. Zakaj potrebujemo raziskovanje in na dokazih podprto prakso v zdravstveni negi? In: Skela-Savič, B., et al. eds. Teoretične in praktične osnove zdravstvene nege. Jesenice: Visoka šola za zdravstveno nego, pp. 28-39.

Skela-Savič, B. \& Robida, A., 2012. Kakovost in varnost zdravstvene obravnave: vloga srednjega menedžmenta. Obzornik zdravstvene nege, 46(1), pp. 9-35. 
Sochan, A.M., 2011. Stance and strategy: post structural perspective and post-colonial engagement to develop nursing knowledge. Nursing Philosophy, 12(3), pp. 177-190. http://dx.doi.org/10.1111/j.1466-769X.2011.00497.x PMid:21668617

Spence Laschinger, H.K., Read, E., Wilk, P. \& Finegan, J., 2014. The influence of nursing unit empowerment and social capital on unit effectiveness and nurse perceptions of patient care quality. The Journal of Nursing Administration, 44(6), pp. 347-352.

http://dx.doi.org/10.1097/NNA.0000000000000080

PMid:24853796

Wyatt, D.A., 2012. Nurses' responsibility for the future of nursing. Association of Operating Room Nurses Journal, 95(5), pp. 565-566. http://dx.doi.org/10.1016/j.aorn.2012.03.007

PMid:22541764
Zakon o zdravstveni dejavnosti (ZZDej-UPB2), 2005. Uradni list Republike Slovenije št. 23.

Železnik, D. \& Filej, B., 2010. Kompetence kot zagotovilo za učinkovito in varno zdravstveno nego. In: Pajnkihar, M., Pirš, K., Harih, M. \& Donik, B. eds. Gradimo učinkovito in zmogljivo zdravstveno nego. Maribor: Društvo medicinskih sester, babic in zdravstvenih tehnikov, pp. 119-126.

Cite as/Citirajte kot:

Filej, B., 2015. Pogled študentov magistrskega študija vzgoje in menedžmenta v zdravstvu na pridobljeno znanje. Obzornik zdravstvene nege, 49(2), pp. 126-135. http://dx.doi.org/10.14528/snr.2015.49.2.40 